\title{
THE CONCENTRATION OF TOTAL UNCONJUGATED OESTROGENS IN THE PLASMA OF PREGNANT GOATS
}

\author{
J. R. G. GHALLIS AND J. L. LINZELL \\ Agricultural Research Council, Institute of Animal Physiology, \\ Babraham, Cambridge
}

(Received 16th March 1971)

Recent work from this laboratory has shown that in the sheep there is a sharp rise in the uterine secretion of unconjugated oestrogens during the last $48 \mathrm{hr}$ of pregnancy (Challis, 1971; Challis, Harrison \& Heap, 1971). In addition, the production of progesterone by the placenta is significantly reduced at this time (Challis, Harrison \& Heap, 1971), and any interpretation of a foetal rôle in the initiation of parturition (Liggins, 1969) must take into account such changes in the levels of steroid hormones in the mother. It was, therefore, of interest to study the pattern of oestrogen secretion in a related species such as the goat in which progesterone is exclusively derived from the ovaries throughout pregnancy (Linzell \& Heap, 1968), and ovariectomy at any stage of gestation results in abortion (Drummond-Robinson \& Asdell, 1926)

The goats used in these experiments were British Alpine (three animals), Saanen (eight), Welsh (one) and Welsh $\times$ Saanen (three) breeds. They were kept in semi-covered yards, and fed hay, cereals, vitamins and minerals throughout the experimental period. Blood samples $(10 \mathrm{ml})$ were taken from the jugular vein by needle puncture into heparinized tubes. The plasma was immediately separated by centrifugation at $4^{\circ} \mathrm{C}$, and was stored at $-15^{\circ} \mathrm{C}$ until analysis. The validity of using jugular venous samples to monitor changes in the circulating oestrogen concentration was checked in two goats, in which one carotid artery and one mammary vein had been exteriorized as skin covered-loops. The concentration of oestrogens in blood taken from these two vessels was not appreciably different from that in the jugular vein.

Total unconjugated oestrogens were measured by a radioimmunoassay procedure (Tillson, Thorneycroft, Abraham, Scaramuzzi \& Caldwell, 1970; Challis, Heap \& Illingworth, 1971), which utilized an antiserum prepared against oestradiol-17 $\beta$. Because this antiserum cross-reacted with oestrone $(90 \%)$ oestradiol- $17 \alpha(36 \%)$ and oestriol $(52 \%)$, the results have been expressed as the total ether-extractable (unconjugated) oestrogens per $\mathrm{ml}$ of plasma. One $\mathrm{ml}$ of plasma was extracted from samples taken early in pregnancy, but after Days 80 to 90 post coitum, $0.3 \mathrm{ml}$ or $0.1 \mathrm{ml}$ was sufficient. All assays were performed in duplicate.

The plasma concentrations of total unconjugated oestrogens in fifteen goats during pregnancy are shown in Text-figs. 1 and 2(a). The day of parturition has been taken as Day 0, and pregnancy has been 'back-dated' from this time. 


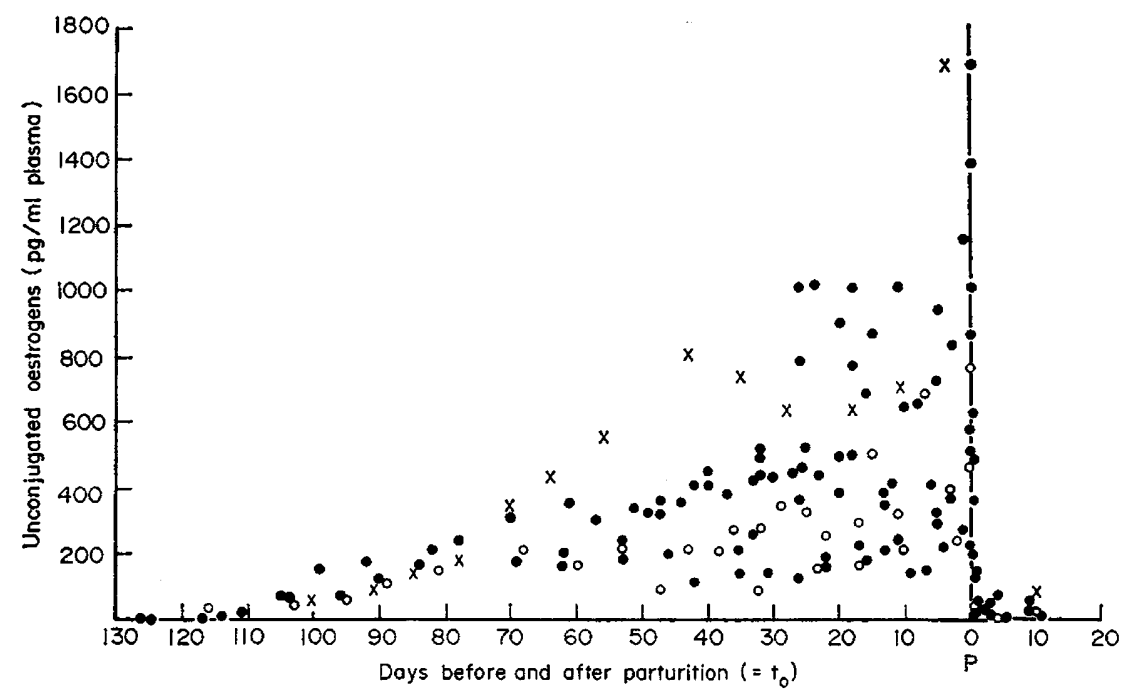

TEXT-FIG. 1. Plasma unconjugated oestrogens in pregnant goats. Animals with one foetus $(0)$, two foetuses $(\bullet)$, three foetuses $(x) . P$ is the day of parturition $(=$ time 0$)$.

The actual length of gestation in this series of fifteen goats ranged from 141 to 155 days (mean: 149; median: 149).

During the first 30 days after mating, the concentrations of plasma oestrogens were less than $5 \mathrm{pg} / \mathrm{ml}$ of plasma. After this time, the mean values for 10-day intervals during gestation increased steadily from $46.5 \pm 14.9 \mathrm{pg} / \mathrm{ml}$ (S.E.;

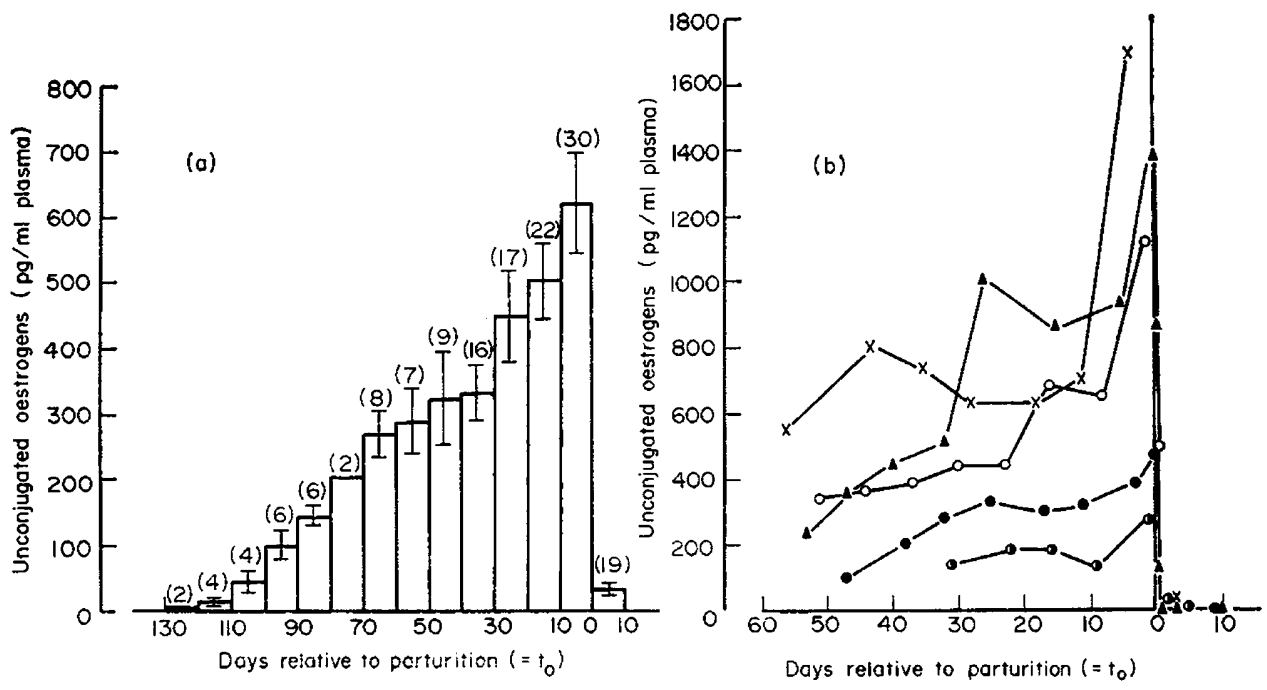

TEXT-FIG. 2. (a) Plasma unconjugated oestrogens in pregnant goats. Mean \pm S.E. of values obtained during 10-day intervals in gestation for all animals studied. $\mathbf{n}=$ number of observations. (b) Plasma unconjugated oestrogens in five individual goats during late pregnancy. $\times$, goat $\mathrm{A150}$, three foetuses, actual length of gestation $=148$ days; $\Delta$, Beauty, two foetuses, 147 days; 0 , W156, two foetuses, 146 days; $\odot$, Millie, one foetus, 155 days; 0 , Heather, two foetuses, 152 days. 
number of observations, $\mathrm{n}=4$; Days 110 to 101 before parturition) to $271 \cdot 6 \pm$ $34 \cdot 8(\mathrm{n}=8$; Days 70 to 61$), 450 \cdot 8 \pm 69 \cdot 7(\mathrm{n}=17$; Days 30 to 21$)$ and to the highest values of $622.4 \pm 77.5(n=30)$, measured during the last 10 days of pregnancy (Text-fig. 2a). In each individual goat, the peak oestrogen concentration was found in the sample taken closest to the time before parturition. Plasma oestrogens fell rapidly after parturition, and in some animals they were undetectable within 1 day, although in others a low residual level was still present in the plasma 10 days after kidding.

Considerable variation in oestrogen levels was found between goats, although individuals tended to have consistently high or low values (Text-figs. 1 and $2 \mathrm{~b}$ ). There was no significant difference in concentration between goats of different parity (one to seven), although the levels in animals carrying a single foetus tended to be amongst the lowest until 20 days before parturition; thereafter, they were within the range for goats carrying twins or triplets. The mean values of samples from three goats with single foetuses taken during three 10-day intervals before parturition were $52 \%, 62 \%$ and $68 \%$ of the mean for animals with two foetuses, although these differences were statistically not significant $(P>0 \cdot 05)$.

The concentrations of oestrogens in five individual goats during the last 60 days of pregnancy are shown in Text-fig. 2(b). Each individual showed a consistent pattern of an increasing oestrogen concentration with advancing gestation. A slight fall was observed in the levels for four of these five goats between 20 and 10 days before parturition, but all five animals had an elevated oestrogen concentration during the last week of pregnancy. In three goats, A150, W156 and Beauty, this was particularly marked and represented an increase of 50 to $100 \%$ over the level in the previous sample taken between 5 and 7 days earlier. The precipitous drop in oestrogen levels after parturition was followed most closely in Beauty, in which the concentration fell from $1380 \mathrm{pg} / \mathrm{ml}$ shortly after the birth of the first kid to $860 \mathrm{pg} / \mathrm{ml}$ about $1 \mathrm{hr}$ after the birth of the second. The placentae were delivered and eaten within $15 \mathrm{~min}$ of the second birth and $3.25 \mathrm{hr}$ later the oestrogen level had fallen to $123 \mathrm{pg} / \mathrm{ml}$. Twenty-four hours later, oestrogens were not detectable in the plasma of this goat.

Preliminary measurements of individual oestrogens following their separation by thin-layer chromatography, indicated that both oestrone and oestradiol$17 \beta$ were present in samples taken from two goats during the last 40 days of gestation, although neither accounted for $>50 \%$ of the total unconjugated fraction. Klyne \& Wright (1957) reported that oestrone and oestradiol-17 $\alpha$ were the major conjugated phenolic steroids in goat's urine during late pregnancy, but oestradiol-17 $\beta$ and oestriol were not excreted. Thus, the urinary pattern of oestrogen metabolites in the pregnant goat is apparently similar to that of the sheep (Fèvre, Piton \& Rombauts, 1965).

The increasing plasma oestrogen concentration during pregnancy in the goat follows a pattern similar to the rise in urinary oestrogens, measured by bioassay (Küst \& Vogt, 1934), but differs from the sheep (Challis, 1971) in that the levels throughout gestation are higher, and the increase associated with parturition is not as dramatic. In the goat (Heap \& Linzell, 1966; Blom \& Lyngset, 1970) and sheep (Bassett, Oxborrow, Smith \& Thorburn, 1969), the 
circulating plasma progesterone concentration falls before parturition. It appears, therefore, that in both these species the myometrial activity associated with the onset of normal parturition may be related to a significant increase in plasma unconjugated oestrogens and a decrease in plasma progesterone levels. The rôle of the foetus in these changes remains to be elucidated.

We are indebted to Dr B. V. Caldwell (Worcester Foundation for Experimental Biology, Boston, Mass., U.S.A.), for providing the antiserum to oestradiol$17 \beta$. We would like to thank $\operatorname{Dr} \mathrm{R}$. B. Heap for his interest in this work and $\mathrm{Mr}$ I. Fleet for his assistance. One of us (J.R.G.G.) gratefully acknowledges the financial support of the Lalor Foundation.

\section{REFERENCES}

Bassett, J. M., Oxborrow, T. J., Smith, I. D. \& Thorburn, G. D. (1969) The concentration of progesterone in the peripheral plasma of the pregnant ewe. $\mathcal{F}$. Endocr. $45,449$.

Blom, A. K. \& Lyngset, O. (1970) Plasma progesterone levels in goats during pregnancy measured by the CBG (corticosteroid-binding globulin) method. Acta physiol. scand. 79, 25A.

Chillis, J. R. G. (1971) Sharp increase in free circulating oestrogens immediately before parturition in sheep. Nature, Lond. 229, 208.

Ghallis, J. R. G., Harrison, F. A. \& Heap, R. B. (1971) Uterine production of oestrogens and progesterone at parturition in the sheep. (Abstract). 7. Reprod. Fert. 25, 306.

Challis, J. R. G., Heap, R. B. \& Illingworth, D. V. (1971) The plasma concentrations of oestrogen and progesterone in non-pregnant, pregnant and lactating guinea-pigs. F. Endocr. (in press).

Drummond-Robinson, G. \& Asdell, S. A. (1926) The relation between the corpus luteum and the mammary glands. F. Physiol., Lond. 61, 608.

Fèvre, J., Prton, C. \& Rombauts, P. (1965) Etude des oestrogènes urinaires chez la brébis gestante. C.r. hebd. Séanc. Acad. Sci., Paris, 261, 2517.

Heap, R. B. \& Linzell, J. L. (1966) Arterial concentration, ovarian secretion and mammary uptake of progesterone in goats during the reproductive cycle. F. Endocr. 36, 389.

KlyNe, W. \& WRIGHT, A. A. (1957) Steroids and other lipids of pregnant goat's urine. Biochem. $\mathcal{F}$ 66, 92.

Küst \& Vogt (1934) Nachweis der Sexualhormone bei der Ziege und ihre Auswertungsmöglichkeit für die hormonale Trächtigkeitsfeststellung. Tierärztl. Rdsch. 40, 589.

Liggrns, G. C. (1969) The foetal role in the initiation of parturition in the ewe. In: Foetal Autonomy, pp. 218-231. Ciba Fdn Symp. Eds. G. E. W. Wolstenholme and M. O'Connor. Churchill, London.

Linzeli, J. L. \& HeAP, R. B. (1968) A comparison of progesterone metabolism in the pregnant sheep and goat: sources of production and an estimation of uptake by some target organs. J. Endocr. 41, 433.

Tillson, S. A., Thorneycroft, I. H., Abraham, G. E., Scaramuzzi, R. J. \& Galdwell, B. V. (1970) Solid-phase radioimmunoassay of steroids. In: Immunological Methods in Steroid Determinations. Eds. F. G. Peron and B. V. Caldwell. Appleton-Century-Crofts, New York. 